52. Working Party Report. Revised guidelines for the control of epidemic methicillin-resistant Staphylococcus aureus. J Hosp Infect 1990;16:351-377.

53. Doebbeling BN, Breneman DL, Neu HC, et al. Elimination of Staphylococcus aureus nasal carriage in healthcare workers: analysis of six clinical trials with calcium mupirocin ointment. Clin Infect Dis 1993;17:466-474.

54. Boelaert JR, De Smedt RA, De Baere YA. The influence of calcium mupirocin nasal ointment on the incidence of Staphylococcus aureus infections in hemodialysis patients. Nephrol Dial Transplant 1989;4:278-281.

55. Leigh DA, Joy G. Treatment of familial staphylococcal infection: comparison of mupirocin nasal ointment and chlorhexidine/ neomycin (Naseptin) cream in eradication of nasal carriage. $J$ Antimicrob Chemother 1993;31:909-917.

56. Kluytmans J, Maat A, Manders M, Wagenvoort J. Reduction of post-operative wound infection by elimination of nasal carriage of Staphylococcus aureus. Proceedings of the 32nd Interscience Conference on Antimicrobial Agents and Chemotherapy 1992;1267:322. Abstract.

57. Tryba M. Risk of acute stress bleeding and nosocomial pneumonia in ventilated intensive care unit patients: sucralfate versus antacids. Am J Med 1987;83(suppl 3B):117-124.

58. Driks MR, Craven DE, Celli BR, et al. Nosocomial pneumonia in intubated patients given sucralfate as compared with antacids or histamine type 2 blockers: the role of gastric colonization. $N$ Engl J Med 1987;317:1376-1382.

59. Eddleston JM, Vohra A, Scott P, et al. A comparison of the frequency of stress ulceration and secondary pneumonia in sucralfate- or ranitidine-treated intensive care unit patients. Crit Care Med 1991;19:1491-1496.

60. Prod'hom G, Leuenberger P, Koerfer J, et al. Nosocomial pneumonia in mechanically ventilated patients receiving antacid, ranitidine, or sucralfate as prophylaxis for stress ulcer: a randomized controlled trial. Ann Intern Med 1994;120:653-662.

61. Simms HH, DeMaria E, McDonald L, Peterson D, Robinson A, Burchard KW. Role of gastric colonization in the development of pneumonia in critically ill trauma patients: results of a prospective randomized trial. J Trauma 1991;31:531-536.

62. Lee B, Chang RWS, Jacobs S. Intermittent nasogastric feeding: a simple and effective method to reduce pneumonia among ventilated ICU patients. Clin Intensive Care 1990;1:100-102.

63. Bonten MJM, Gaillard CA, Hoefnagels J, et al. The influence of intermittent enteral feeding on intragastric acidity on colonization of stomach and oropharynx. Proceedings of the 34th Interscience Conference on Antimicrobial Agents and Chemotherapy; Orlando, FL; 1994. Abstract.

64. Spilker CA, Hinthorn DR, Pingleton SK. Intermittent enteral feeding and gastric colonization in critically ill patients. $\mathrm{Am} \mathrm{Rev}$ Respir Dis 1993;147:A200. Abstract.

65. Heyland D, Bradley C, Mandell LA. Effect of acidified enteral feedings on gastric colonization in the critically ill patients. Crit Care Med 1992;20:1388-1394.

66. Montecalvo MA, Steger KA, Farber HW, et al. Nutritional outcome and pneumonia in critical care patients randomized to gastric versus jejunal feedings. Crit Care Med 1992;20:1377-1387.

67. Rutter JM, Jones GW. Protection against enteric disease caused by Escherichia coli-a model for vaccination with a virulence determinant? Nature 1973;242:531.

68. Silverblatt FJ, Cohen LS. Antipili antibody affords protection against experimental ascending pyelonephritis. J Clin Invest 1979;64:333.

69. Ofek I, Beachey EH, Eisenstein BI. Suppression of bacterial adherence by subminimal inhibitory concentrations of betalactam and aminoglycoside antibiotics. Rev Infect Dis 1979;1:832.

\title{
Conference on Reuse of Medical Devices
}

\section{by Gina Pugliese, RN, MS Medical News Editor}

The Association for the Advancement of Medical Instrumentation is collaborating with a number of organizations to cosponsor a conference on "Designing, Testing, and Labeling Reusable Medical Devices for Reprocessing in Healthcare
Facilities" to be held April 9-10, 1996, in Washington DC. Cosponsoring organizations include the Health Industry Manufacturer Association, the Food and Drug Administration, American Medical Association, the Association for Professionals in Infection Control and Epidemiology, and the Association of Operating Room Nurses.
Conference topics will include reprocessing techniques, the perspective of technicians, an overview of standards and regulations, device design considerations, manufacturer responsibilities regarding reusable devices, and the future of reprocessing.

For more information, call (703) 525-4890, ext 260 . 